\title{
Molecular cloning, expression and biochemical characterisation of a cold-adapted novel recombinant chitinase from Glaciozyma antarctica PI12
}

Aizi Nor Mazila Ramli ${ }^{1}$, Nor Muhammad Mahadi ${ }^{2}$, Amir Rabu $^{3}$, Abdul Munir Abdul Murad ${ }^{3}$, Farah Diba Abu Bakar ${ }^{3}$ and Rosli Md Illias ${ }^{1 *}$

\begin{abstract}
Background: Cold-adapted enzymes are proteins produced by psychrophilic organisms that display a high catalytic efficiency at extremely low temperatures. Chitin consists of the insoluble homopolysaccharide $\beta$ - $(1,4)$ linked $\mathrm{N}$-acetylglucosamine, which is the second most abundant biopolymer found in nature. Chitinases (EC 3.2.1.14) play an important role in chitin recycling in nature. Biodegradation of chitin by the action of cold-adapted chitinases offers significant advantages in industrial applications such as the treatment of chitin-rich waste at low temperatures, the biocontrol of phytopathogens in cold environments and the biocontrol of microbial spoilage of refrigerated food.
\end{abstract}

Results: A gene encoding a cold-adapted chitinase (CHI II) from Glaciozyma antarctica Pl12 was isolated using Rapid Amplification of cDNA Ends (RACE) and RT-PCR techniques. The isolated gene was successfully expressed in the Pichia pastoris expression system. Analysis of the nucleotide sequence revealed the presence of an open reading frame of 1,215 bp, which encodes a 404 amino acid protein. The recombinant chitinase was secreted into the medium when induced with $1 \%$ methanol in BMMY medium at $25^{\circ} \mathrm{C}$. The purified recombinant chitinase exhibited two bands, corresponding to the non-glycosylated and glycosylated proteins, by SDS-PAGE with molecular masses of approximately 39 and $50 \mathrm{kDa}$, respectively. The enzyme displayed an acidic pH characteristic with an optimum pH at 4.0 and an optimum temperature at $15^{\circ} \mathrm{C}$. The enzyme was stable between $\mathrm{pH} 3.0-4.5$ and was able to retain its activity from 5 to $25^{\circ} \mathrm{C}$. The presence of $\mathrm{K}^{+}, \mathrm{Mn}^{2+}$ and $\mathrm{Co}^{2+}$ ions increased the enzyme activity up to $20 \%$. Analysis of the insoluble substrates showed that the purified recombinant chitinase had a strong affinity towards colloidal chitin and little effect on glycol chitosan. $\mathrm{CHI}$ II recombinant chitinase exhibited higher $V_{\max }$ and $K_{\text {cat }}$ values toward colloidal chitin than other substrates at low temperatures.

Conclusion: By taking advantage of its high activity at low temperatures and its acidic pH optimum, this recombinant chitinase will be valuable in various biotechnological applications under low temperature and acidic $\mathrm{pH}$ conditions.

Keywords: Cold-adapted chitinase, Glaciozyma antarctica, PI12. Psychrophilic yeast, Pichia pastoris

\footnotetext{
* Correspondence: r-rosli@utm.my

'Department of Bioprocess Engineering, Faculty of Chemical Engineering,

Universiti Teknologi Malaysia, 81310 Skudai, Johor, Malaysia

Full list of author information is available at the end of the article
} 


\section{Background}

Extremophiles are microorganisms that can grow and thrive in extreme environments. Proteins, especially enzymes, isolated from the extremophiles are of particular interest because of their ability to function effectively and remain stable near extreme conditions [1]. Psychrophiles are organisms that live at very low temperatures and can be found in several perennially cold environments, such as the Antarctic. The survival of the psychrophilic organisms at low temperatures (coldadaptation) are due to several factors such as temperature sensing, reduced membrane fluidity, stabilised inhibitory nucleic acid structures, the formation of intracellular crystalline ice and cellular responses that counteract solute uptake rates and lowered enzyme reactions [2]. Recently, psychrophilic enzymes are becoming more attractive in industrial applications, partly because of ongoing efforts to decrease energy consumption. At low temperatures, the kinetic energy of reacting molecules is too low to allow reactions to occur. Psychrophilic or cold-adapted enzymes compensate in this situation by having a highly flexible protein structure and conformation, thereby increasing their thermolability and a high catalytic efficiency at a low energy cost $[2,3]$. To date, many cold-adapted enzymes have been successfully isolated and their expression studies have also been conducted. This includes the glycosyl hydrolase group of enzymes, such as lipases [4], $\alpha$ Amylases [5] and chitinases [6,7].

Chitin is the most abundant biopolymer found in nature after cellulose and attracted special interest as a reusable material $[6,8]$. This polysaccharide is a crucial structural component in fungal cell walls and certain green algae and is a major constituent in the shells, cuticles and exoskeletons of worms, molluscs and arthropods, including crustaceans and insects [7]. Chitin comprises 20 to $58 \%$ of the dry weight of the marine invertebrates, which include shrimp, crabs, squids, oysters and cuttlefish [9]. The enormous amounts of chitin continuously generated in nature require disposal and recycling on a formidable scale [10]. Previous studies revealed the broad range applications of chitin in various biochemical, food and chemical industries. Patil et al. [11] showed that chitin can be used in human health care as an antimicrobial, anticholesterol or antitumor agent. Chitin and its derivatives are also used in wastewater treatment, drug delivery, wound healing and dietary fibre [12]. Due to chitin's important biological role, its synthesis and degradation has been the subject of extensive research.

Chitinases catalyse the hydrolysis of $\beta$-1, 4-linkages in chitin. Many organisms produce chitinases for different purposes [13]. Chitinases produced by bacteria and plants are important for nutritive purposes and in fungal invasion, respectively. All chitin-containing organisms such as fungi and yeast produce chitinases (EC 2.4.1.14) and chitin synthase (EC 2.4.1.16) to mediate cell wall synthesis and growth $[12,14]$. Chitinases are classified into two families of glycosyl hydrolases, family 18 and family 19 , based on the amino acid sequence of the catalytic regions [15]. Family 18 contains chitinases from bacteria, fungi, viruses, animals and some plants [7]. Cold-adapted chitinases are always characterised by low optimal temperatures and increased structural flexibility that is achieved through a combination of structural features [16]. Heat labile and cold-adapted chitinases have been reported from several psychrophilic bacteria $[7,17]$, plants [18] and fungi [19]. However, a cold-adapted chitinase from psychrophilic or psychrotolerant yeast has yet to be reported.

Due to difficulties in getting significant amount of native chitinase of G. antarctica PI12 for protein purification, initial expression of the CHI II gene was carried out in E. coli system. However no expression was observed (data not shown). This could be due to the reduced stability of recombinant psychrophilic proteins expressed in a mesophilic host such as E. coli $[20,21]$. An alternative host to $E$. coli is the methylotrophic yeast, $P$. pastoris which can be regarded as a moderate psychrotrophic organism that can grow at temperature as low as $12^{\circ} \mathrm{C}$. This strain has emerged as a powerful and inexpensive expression system for the production of the eukaryotic recombinant proteins [22].

In this study, we described the isolation and recombinant expression of a psychrophilic chitinase (CHI II) gene from G. antarctica PI12 in P. pastoris. Purification and characterisation of the expressed recombinant $\mathrm{CHI}$ II were also conducted. Subsequent biochemical characterisation of this enzyme suggests its usefulness in some biotechnology applications.

\section{Results and Discussion}

\section{Cloning and sequence analysis of $\mathrm{CHI}$ II from G. antarctica PI12}

A nucleotide sequence obtained from a GSS survey of the G. antarctica PI12 genome was identified to encode the consensus domain of the glycosyl hydrolase family 18 using NCBI databases. Further analyses suggest that the nucleotide sequence encoded part of a chitinase gene sequence. Isolation of the full-length chitinase gene was accomplished by RT-PCR followed by RACE amplification. A DNA fragment of approximately 500 bp was obtained from the RT-PCR method. Due to a lack of DNA information for the G. antarctica PI12 chitinase, RACE techniques were used to amplify the full-length cDNA sequence. The RACE method was 
conducted using the RNA of G. antarctica PI12 and the 5 ' and 3' portion sequence of the full-length cDNA was obtained by 5' and 3' RACE, respectively. About 1100 bp was amplified from 5' RACE and approximately 1200 bp from 3' RACE. Conjugation of the 5' and 3' fragments revealed a full-length chitinase cDNA of $1215 \mathrm{bp}$ containing a $404 \mathrm{bp}$ ORF, a 448 bp 5' untranslated region and a $121 \mathrm{bp}$ untranslated flank at 3' end. The latter includes a polyadenylation signal AATAAA located $23 \mathrm{bp}$ to the 5' side of the poly A tail and a ATTTA sequence, which is involved in the targeting of mRNAs for rapid turnover. Based upon the RACE sequences, a set of primers was designed (CHI-For and CHI-Rev) and the full-length cDNA sequence was amplified via the RT-PCR method. The cDNA sequence was deposited into GenBank with the Accession No.: JF901326.

The DNA sequence encodes a 404 amino acid protein with a calculated molecular weight of $42.9 \mathrm{kDa}$ and a theoretical pI of 9.65. Previous studies reported that the chitinases from various organisms had a molecular mass of about 40-80 kDa. The recombinant chitinase from Clonostachys rosea had a molecular mass of $43.8 \mathrm{kDa}$ [23], whereas the recombinant chitinase from Chaetomium cupreum and Vibrio sp. Fi:7 was found to have a molecular mass of $58 \mathrm{kDa}$ [24] and 79.4 kDa [25], respectively. A SignalP [26] prediction revealed that the CHI II protein contains a putative $\mathrm{N}$-terminal signal peptide of 19 amino acids in length with a predicted cleavage site located between A19 and E18 (THA|||EL). This result suggested that this enzyme is secretory in nature. Analysis of the CHI II sequence by NetNGlyc 1.0 Server [27] showed that there is one potential Nlinked glycosylation site at position -371. Interproscan [28] analysis predicted that CHI II encodes a glycosyl hydrolase family 18 member because of the amino acid segment "FDGVDLDWE" at nucleotide position 498, which matches the consensus catalytic sequence pattern [LIVMFY]-[DN]-G-[LIVMF]-[DN]-[LIVMF]-[DN]-X-E of chitinases in family 18 glycosyl hydrolases. The CHI II InterPro Accession No. is IPR001223, indicating that it is a novel member of the family 18 glycosyl hydrolases (endochitinase) and belongs to the chitinase class II.

Based on a Blast search analysis, CHI II showed low similarity to all proteins in the database with an identity of $34 \%$ to chitinase from Puccinia triticina and 33\% to endochitinase from Amanita muscaria. A low identity of the CHI II sequence with the available sequences in the database suggested that this chitinase from G. antarctica PI12 was a newly isolated chitinase sequence from yeast. CHI II appears to be a simple and compact chitinase with an $\mathrm{N}$-terminal sequence encoding for a signal peptide and a $\mathrm{C}$-terminal catalytic domain $(\mathrm{CaD})$.
Interestingly, neither the chitin-binding domain (CBD) nor the Ser/Pro/Thr rich linker, which were often associated with the catalytic domain in family 18 chitinases, was found in CHI II (Figure 1). This finding supports the study by Wang et al. [29] that showed that a single $\mathrm{CaD}$ is sufficient for the catalytic activity of chitinase and further suggested that the CBD may facilitate hydrolysis of an insoluble substrate [30] but was not required for chitinase activity. Figure 1 shows the domain organisations of family 18 chitinases that demonstrates the similarity of the CHI II domain structure with the chitinase from Bacillus cereus (chi36) [29] and the differences from others. It is unclear whether CHI II from G. antarctica PI12 evolved from multidomain chitinases as an alternative mechanism to proteolytic cleavage for the acquisition of high efficiency soluble chitinolytic activity.

A multiple sequence alignment of the catalytic domain was conducted using the DNAMAN programme (Figure 2). Five catalytic domains of chitinases from other eukaryotes were chosen and aligned based on their strong identity to the chitinase from G. antarctica PI12. This core region contains two conserved amino acid regions, each consisting of SxGG and DxxDxDxE, which are highly conserved among the family 18 chitinases and may constitute the catalytic pocket $[15,23]$. Importantly, residues that are essential for chitinase activity, particularly Asp144, Asp147, Asp149 and Glu151, were also observed in the CHI II catalytic domain, implying the crucial role of these residues in the catalytic activity and structure of chitinases [31].

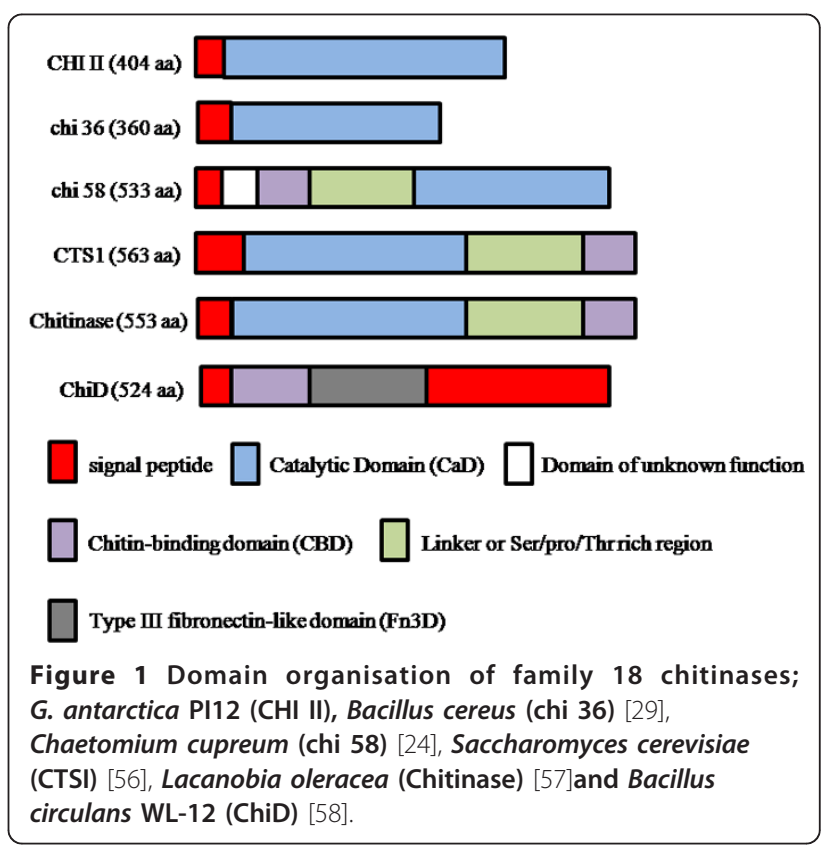




\begin{tabular}{|c|c|c|}
\hline L.antarcticum & VKSKPLITVGCẄTGSVYISALISTSSKRTPFAKTLLAFVN & 139 \\
\hline A.muscaria & ENVGALUSIGEKTGSCYYSTLMQPSNQA. P FVNTIVSMVK & 147 \\
\hline C. congregatus & HNVKALISVGCRTGSRF FSTAVATPQNRTA EVKTVIDFVR & 153 \\
\hline L.bicolor & SNVATAANRTIFVKTLTCLVT & 138 \\
\hline P.triticina & YKVNPLFSTGCЙTGSRASNLTSTDAARKRFAQILVCEFK & 139 \\
\hline T. camphoratus & NGVKAMVSTGCWEGSYHSSLVATQDNRTPEVKTITLFAQ & 138 \\
\hline \multicolumn{3}{|l|}{ Consensus } \\
\hline L.antarcticum & VAVIR & 179 \\
\hline A.muscaria & LSFLQKIR & 187 \\
\hline C.congregatus & NFLLYLQELR & 193 \\
\hline L.bicolor & NFLLFLQELR & 178 \\
\hline P.triticina & NFGLLVKEIR & 179 \\
\hline T. camphoratus & TYNLDEIDIDWEY & 178 \\
\hline Consensus & $\alpha \propto n$ & \\
\hline \multicolumn{3}{|c|}{$\begin{array}{l}\text { Figure } 2 \text { Multiple sequence alignment of the core region of the catalytic domains between CHI II and some eukaryotic chitinases } \\
\text { Highly conserved regions, SxGG and DxxDxDxE, are boxed. Residues responsible for the catalytic activity are indicated with asterisks. Sequence } \\
\text { fragments displaying the typical motifs with the G. antarctica PI12 catalytic domain include Amanita muscaria, Laccaria bicolor, Coprinellus } \\
\text { congregatus, Puccinia triticina and Taiwanofungus camphorates. }\end{array}$} \\
\hline
\end{tabular}

Multiple sequence alignment and phylogenetic analysis To investigate the evolutionary relationship among the cold-adapted chitinase identified in this work and others reported in the literature, phylogenetic analysis was performed. The search for complete protein sequence was explored using the NCBI BlastP service. A total of 24 chitinase sequences (all hits with an e-value lower than $6 \times 10^{-20}$ ) were downloaded and aligned using clustal X. From this alignment, a NJ tree was constructed to examine the distances among these sequences. An NJ tree was then inferred and the tree topology was analysed using bootstrapping (1000 replicates). The chitinase of Streptomyces griseus, which did not coincide with the taxonomic status of the CHI II, was used as an out-group in order to root the tree.

The analysis summarised in Figure 3 shows that the chitinase sequences clustered into two supported subgroups corresponding to clade I and II, which are both monophyletic clades. The monophyletic lineages provided a support for the hypothesis that clade I and II chitinases are likely to have evolved from one common ancestor [32]. Clade I consists of two subclades; chitinases from Vertebrate and Insecta were clustered and formed the subclade Ia, while chitinases from the bacteria domain (Firmicutes, Proteobacteria and Bacteroidetes) were clustered and formed the subclade Ib. Chitinases from Basidiomycota and Archaea were clustered and formed the second monophyletic clade (clade II) that consisted of subclade IIa (Basidiomycota) and subclade
IIb (Archaea). CHI II chitinase from G. antarctica PI12 was clustered in the Basidiomycota group, which was well supported by bootstrapping (NJ: 100\%). Homology values ranging between 21 to $54 \%$ were found when comparing CHI II with the other Basidiomycota chitinases. Orikoshi et al. [17] found that the redundancy of the chitinase genes within the same species may reflect their functional difference between related proteins and also the adaptive evolution of the chitinases. Bootstrap values, an index of the accuracy of the phylogenetic tree, were found to be higher outside the tree but lower inside the tree, which may indicate the low relative diversity of all the sequences used in the analysis [33].

\section{Heterologous expression of the recombinant $\mathrm{CHI}$ II in $P$. pastoris}

The expression of CHI II was conducted in a $P$. pastoris expression system. Culture condition is one of the critical parameters that significantly affect cell growth and the yield of recombinant product. Stress imposed by cultivation conditions or strategies can lead to a decrease in cell viability, which in turn lowers productivity and induces cell lysis [34]. In this study, the highest extracellular chitinase activity was found to be $1.24 \mathrm{U} \mathrm{ml}^{-1}$ at $120 \mathrm{~h}$ postinduction when cells were grown in BMMY medium $(\mathrm{pH}$ 6.0) at $25^{\circ} \mathrm{C}$ with $1 \%(\mathrm{v} / \mathrm{v})$ methanol as inducer. Yield of the recombinant CHI II expressed in P. pastoris was shown to be significantly improved at low temperatures. This could be due to the characteristic of psychrophilic 


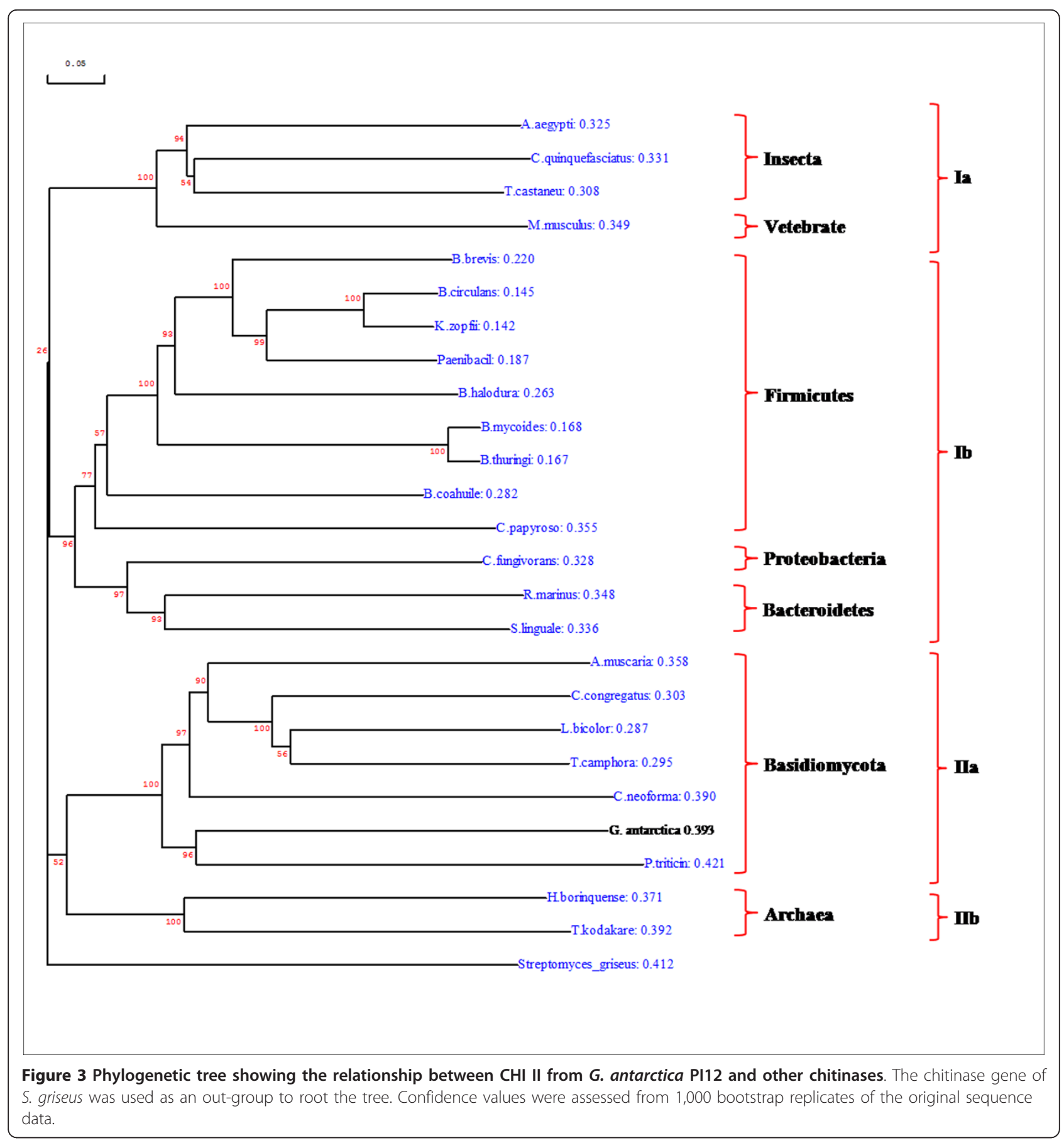

proteins to be stable at low temperatures when compared with other mesophilic chitinases [24,31] expressed in $P$. pastoris. Hong et al. [35] reported that high cultivation temperatures can induce the release of proteases from dead cells and may also affect the protein folding process. SDS-PAGE and western blotting analysis of the crude supernatants at the inducible period from 24 to $120 \mathrm{~h}$ showed two clearly visible protein bands with a molecular mass of approximately 39 and $50 \mathrm{kDa}$, respectively
(Figure $4 \mathrm{a}$ and $4 \mathrm{~b}$ ). This study shows that P. pastoris is the suitable host for the production of cold-adapted protein such as CHI II. Similar finding for the high yield production of recombinant protein in methylotrophic yeast $P$. pastoris was obtained for other cold-adapted chitinase such as in the case of endochitinase from Sanguibacter antarcticus [36].

The recombinant chitinase CHI II protein (encoding CHI II mature protein) had an apparent molecular mass 


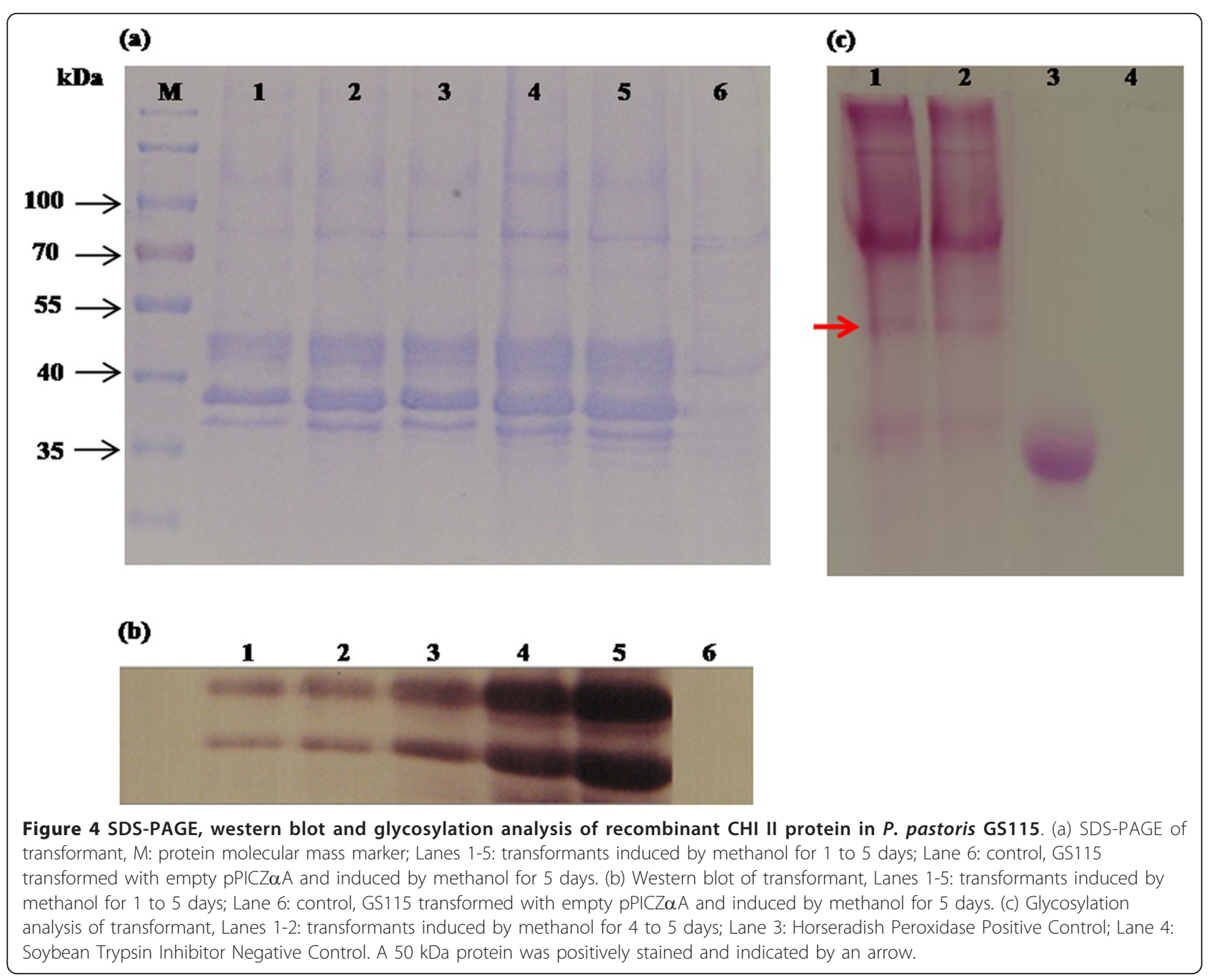

of about $39 \mathrm{kDa}$, less than the theoretically calculated molecular mass of $40.86 \mathrm{kDa}$. Another apparent band of about $50 \mathrm{kDa}$ is higher than the calculated molecular mass and was predicted to be post-translationally modified and a glycosylated form of CHI II in P. pastoris. A GelCode Glycoprotein Staining kit was used to confirm the glycosylated moiety of the expressed chitinase in the polyacrylamide gel. As presented in Figure 4c, the 50 $\mathrm{kDa}$ band was positively stained, appearing as a magenta band with light pink background, whereas the $39 \mathrm{kDa}$ band was not, indicating that the $50 \mathrm{kDa}$ band was glycosylated. One putative N-glycosylation site (Asn-Xaa$\mathrm{Thr} / \mathrm{ser}$ ) was found in the mature protein when the amino acid sequence were analysed using NetNGlyc 1.0 Server [27], while there was four potential O-glycosylation sites predicted using NetOGlyc 3.0 Server [37]. In eukaryotes, enhanced protein stability is often achieved by glycosylation resulting in protection by the attached sugar moieties. In P. pastoris, N-glycosylation is a common post-translational modification that enhances protein stability. Previous studies of chitinases from Haemaphysalis longicornis [38] and Oryza sativa L. [39] found larger proteins than the predicted molecular masses, implying that these chitinase proteins underwent post-translational modification.

\section{Enzymatic properties of purified $\mathrm{CHI}$ II}

To examine the catalytic properties of CHI II produced by $P$. pastoris, the recombinant enzyme was purified to homogeneity using HisTrap TM HP Columns from GE Healthcare. The purified recombinant chitinase CHI II was resolved as two bands by SDS-PAGE as shown in Figure 5.

To determine the $\mathrm{pH}$ and temperature optima of the $\mathrm{CHI}$ II, the enzyme's activity was assayed at different $\mathrm{pH}$ levels and temperatures. The effect of $\mathrm{pH}$ on the chitinolytic activity was studied with a citrate-phosphate buffer (pH 2.5 to 6.5) and a potassium phosphate buffer ( $\mathrm{pH} 6.0$ to 8.0). Purified CHI II exhibited enzymatic activity over a $\mathrm{pH}$ range of 2.5 to 6.5 (measured at $15^{\circ} \mathrm{C}$ ) and the 


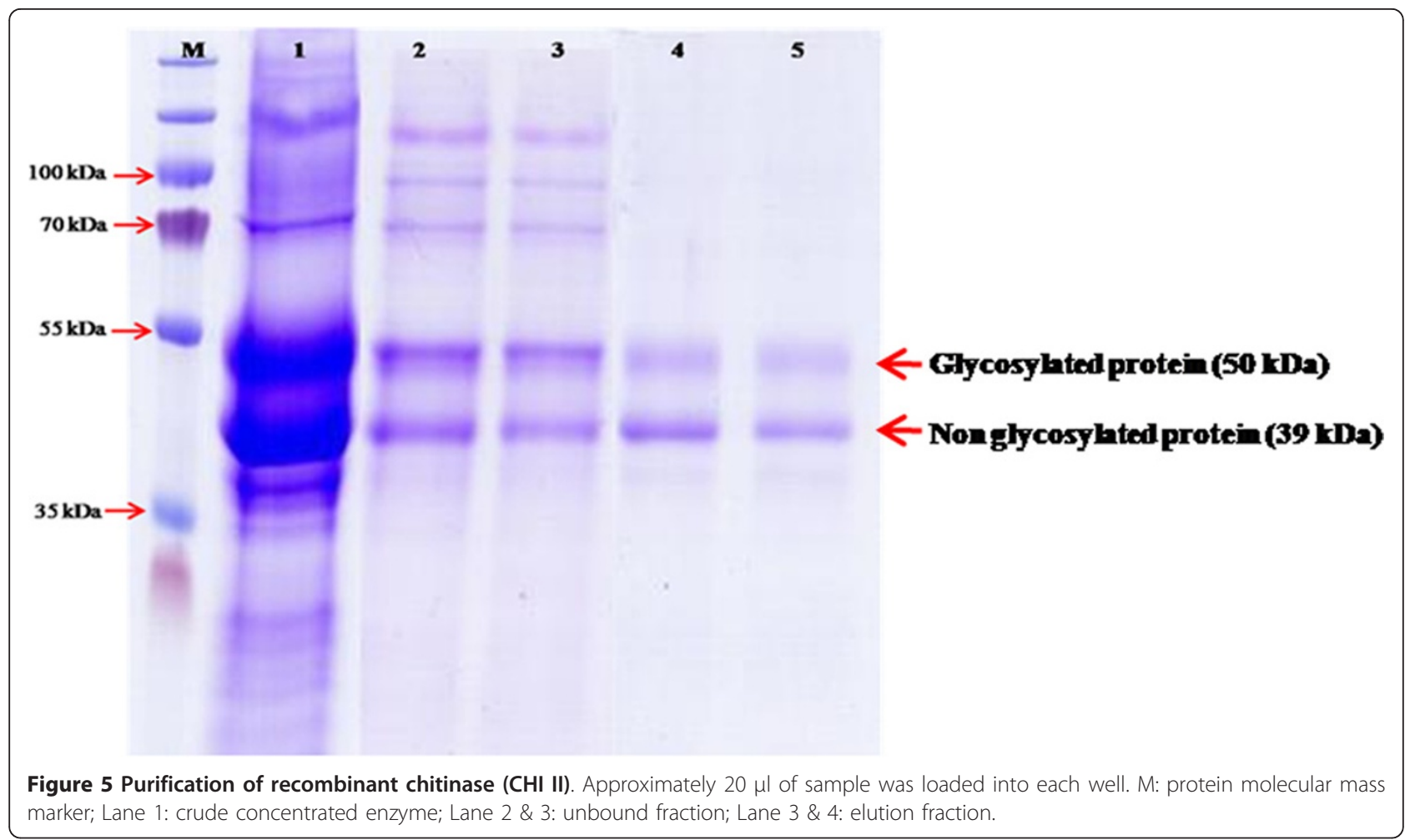

activity of the purified chitinase was increased with increasing $\mathrm{pH}$ up to $\mathrm{pH} 4.0$ in citrate-phosphate buffer. It was found that the optimal $\mathrm{pH}$ was 4.0 with more than $80 \%$ of the relative chitinase activity retained at the acidic condition of $\mathrm{pH} 3.5$, as shown in Figure 6a. Alternatively, the optimum $\mathrm{pH}$ for chitinases produced by the psychrotolerant bacterium Vibrio sp. strain Fi:7 was pH 8.0 [25] while cold-adapted chitinase $(\mathrm{ChiB})$ from a marine bacterium, Alteromonas sp. Strain O-7 is pH 6.0 [17]. At pH 4.5 , the enzyme activity began to decline, resulting in a relative chitinase activity below $80 \%$, while at $\mathrm{pH} 6.5$, the relative activity was only about $10 \%$. Even though the chitinase activity declined, purified chitinase was found to be stable. More than $80 \%$ of the maximum activity was
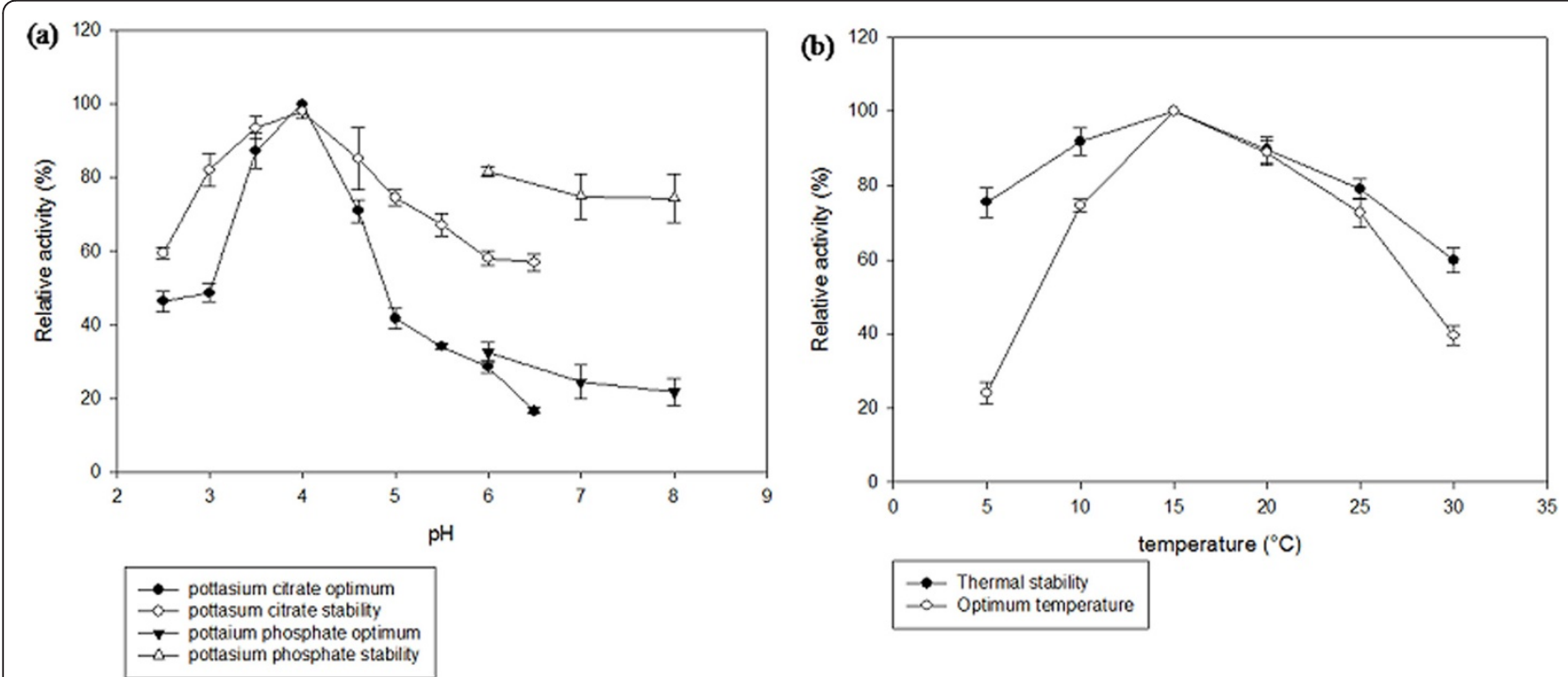

Figure 6 Effect of $\mathrm{pH}(\mathrm{a})$ and temperature (b) on chitinase activity and stability. The highest chitinase activity was set to $100 \%$. 
retained at $\mathrm{pH} 3.0$ to 3.5 , but activity began to be lost after an incubation at a $\mathrm{pH}$ over 4.0. Extreme $\mathrm{pH}$ levels reduced the enzyme's ability to perform its catalytic activity. Most of the fungal chitinolytic enzymes have an optimum $\mathrm{pH}$ between 4.0 and 7.0 [40].

The effects of temperature on the recombinant chitinase's activity and stability were also determined. The optimum temperature for CHI II activity was $15^{\circ} \mathrm{C}$ (Figure $6 \mathrm{~b}$ ). The thermal stability of chitinase was measured by incubating an aliquot of the enzyme at different temperatures for $30 \mathrm{~min}$ and then assaying the residual activity under optimal $\mathrm{pH}$ and temperature conditions. Chitinase was stable at $15^{\circ} \mathrm{C}$ for $30 \mathrm{~min}$ and retained more than $90 \%$ of its initial activity when incubated at $10^{\circ} \mathrm{C}$. Incubation at $20^{\circ} \mathrm{C}$ resulted in a $20 \%$ loss of the residual activity, while more than $70 \%$ of the maximal activity was retained when the enzyme was incubated at $5^{\circ} \mathrm{C}$ and $25^{\circ} \mathrm{C}$. Moreover, the residual activity of the enzyme was $50 \%$ lower when incubated at $30^{\circ}$ C. In general, cold-adapted enzymes display an apparent optimal activity shifted toward low temperatures and also heat lability [17]. It has been proposed that increased flexibility is the most important factor for the catalytic efficiency of cold-adapted enzymes at low temperatures [17], which is achieved through a combination of structural features [16]. Noticeably, the optimum temperature of $\mathrm{CHI}$ II $\left(15^{\circ} \mathrm{C}\right)$ was much lower than those reported for the chitinase from Moritella marina $\left(28^{\circ} \mathrm{C}\right)$ [7], cold-adapted chitinase B of Alteromonas sp. strain O-7 $\left(30^{\circ} \mathrm{C}\right)$ [17] and chitinase A of Vibrio sp. strain Fi:7 $\left(30^{\circ} \mathrm{C}\right)[25]$, yet the reasons for this finding remain unclear.

The catalytic activity of CHI II was strongly affected by the addition of $\mathrm{Ca}^{2+}$ and $\mathrm{Fe}^{2+}$ and was moderately inhibited by the other metal ions, such as $\mathrm{Na}^{+}, \mathrm{Zn}^{2+}$ and $\mathrm{Cu}^{2+}$, which is comparable to the endochitinase from Bacillus cereus [41] (Figure 7). Chitinases from different fungi exhibit different responses to various metal ions [24]. It was reported that EDTA was an inhibitor of chitinase, e.g., it inhibited the chitinase from Enterobacter sp. NRG4 [9]. However, the addition of EDTA did not affect the catalytic activity of CHI II, suggesting that these chitinases may have different catalytic mechanisms. Differing from the Trichoderma virens UKM-1 endochitinase [42], which was completely inhibited by $\mathrm{Mn}^{2+}$ and $\mathrm{Co}^{2+}$, CHI II was activated by the presence of both $\mathrm{Mn}^{2+}$ and $\mathrm{Co}^{2+}$, which enhanced the activity about 10 to $20 \%$. Moreover, $\mathrm{K}^{+}$also increased the activity of the recombinant $\mathrm{CHI}$ II to about $15 \%$, while the CHI46 chitinase from Chaetomium globosum was inhibited by $\mathrm{K}^{+}$[31]. These results showed that chitinases could be activated or inhibited by certain metal ions. However, the chitinases from different species may be stimulated or inhibited by different ions.

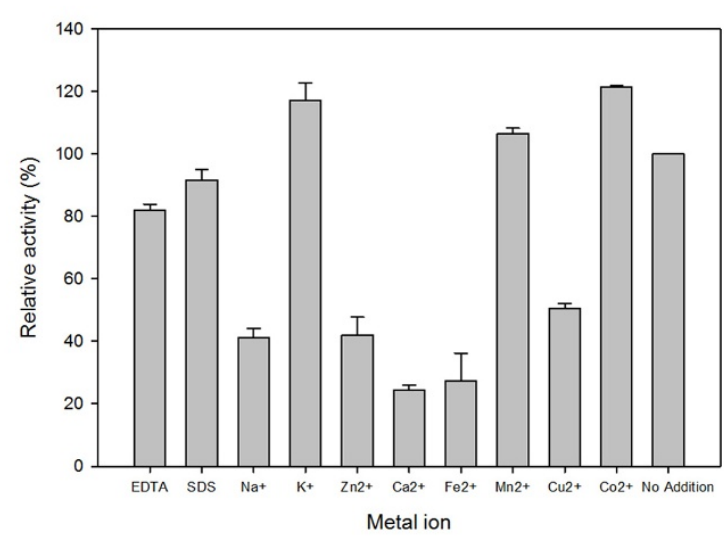

Figure 7 Effect of metal ions and reagents on the recombinant CHI II chitinase activity. No addition (with no metals added to the enzyme solutions) was used for $100 \%$ relative activity.

Chitinases from different sources can use a variety of substrates. In this study, CHI II showed the highest activity toward colloidal chitin $(0.690 \mathrm{U} / \mathrm{ml})$ followed by swollen chitin $(0.570 \mathrm{U} / \mathrm{ml})$, carboxymethyl chitosan $(0.465 \mathrm{U} / \mathrm{ml})$, and glycol chitosan $(0.278 \mathrm{U} / \mathrm{ml})$. When a native chitinase from G. antarctica PI12 were tested against the same substrates, highest activity was exhibited with colloidal chitin $(0.424 \mathrm{U} / \mathrm{ml})$, followed by swollen chitin $(0.340 \mathrm{U} / \mathrm{ml})$, carboxymethyl chitosan $(0.320$ $\mathrm{U} / \mathrm{ml})$, and glycol chitosan $(0.0615 \mathrm{U} / \mathrm{ml})$. These observations show similar activity profile between the recombinant and native chitinase. The preference for hydrolysis of colloidal chitin over other substrates probably reflects that increased accessibility of colloidal chitin to the chitinase active site due to the removal of lipids and proteins from the crab shell chitin after acid hydrolysis treatment [43], while glycol chitosan is chemically different. The higher specificity to the colloidal chitin substrate was similar to that from Trichoderma virens [42]. However, its low hydrolytic activity against glycol chitosan was different from a previous study of chitinase from Schizophyllum commune [44].

Using the purified enzyme of CHI II, kinetic experiments were performed at a temperature of $15^{\circ} \mathrm{C}$ by varying the substrate concentration in a standard activity test from $2.0-10.0 \mathrm{mg} \mathrm{ml}^{-1}$. On the basis of the Lineweaver-Burk plot, the values of kinetic constants $\mathrm{K}_{\mathrm{m}}, \mathrm{V}_{\max }$, and subsequently $\mathrm{k}_{\mathrm{cat}}$, and $\mathrm{k}_{\mathrm{cat}} / \mathrm{K}_{\mathrm{m}}$ of CHI II towards different substrates (colloidal chitin, swollen chitin and carboxymethyl chitosan) were calculated as shown in Table 1. Using colloidal chitin as a substrate, a higher value of $\mathrm{V}_{\max }$, which was $3.559 \mu \mathrm{mol} \mu \mathrm{g}^{-1} \mathrm{~h}^{-1}$, was achieved compared to other substrates. The higher $\mathrm{V}_{\max }$ value indicates the higher efficiency of the enzyme and 
Table 1 Kinetic parameters of $\mathrm{CHI}$ II on different chitin substrates

\begin{tabular}{|c|c|c|c|c|}
\hline & $\begin{array}{l}V_{\max } \\
\left(\mu \mathrm{mole} \mu \mathrm{g}^{-1} \mathrm{~h}-\right. \\
\left.{ }^{1}\right)\end{array}$ & $\begin{array}{l}\mathrm{K}_{\mathrm{m}} \\
\left(\mathrm{mg} \mathrm{ml}^{-}\right. \\
\left.{ }^{1}\right)\end{array}$ & $\begin{array}{l}K_{\text {cat }} \\
s^{-1}\end{array}$ & $\begin{array}{l}\mathrm{k}_{\mathrm{cat}} / \mathrm{K}_{\mathrm{m}} \\
\mathrm{ml}^{-1} \mathrm{mg}^{-1} \mathrm{~s}^{-}\end{array}$ \\
\hline Colloidal chitin & 3.559 & 27.918 & 0.915 & 0.0328 \\
\hline Swollen chitin & 2.695 & 13.83 & 0.693 & 0.0501 \\
\hline $\begin{array}{l}\text { Carboxymethyl } \\
\text { chitosan }\end{array}$ & 2.725 & 26.79 & 0.701 & 0.0262 \\
\hline
\end{tabular}

suggests that CHI II chitinase has a higher catalytic efficiency towards colloidal chitin as compared to the swollen chitin and carboxymethyl chitosan. The $K_{m}$ values of CHI II against different substrates were $27.918 \mathrm{mg} \mathrm{ml}^{-1}$, $13.83 \mathrm{mg} \mathrm{ml}^{-1}$ and $26.79 \mathrm{mg} \mathrm{ml}^{-1}$, with colloidal chitin, swollen chitin, and carboxymethyl chitosan, respectively, which are comparatively higher than the other reports in literature [45,46]. Stefanidi et al. [7] suggested that enzymes produced by marine bacteria work at saturating concentrations of chitin and showed the high values of the $K_{m}$ constant. On the contrary, some cold-adapted enzymes have a lower $K_{m}$ than their thermostable homologues. For secreted enzymes from marine microorganisms, the requirement for a low $K_{m}$ may relate to the need to scavenge substrates that are at low concentrations in the environment [47].

Furthermore, the $\mathrm{K}_{\mathrm{cat}}$ value of CHI II was also found to be highest with colloidal chitin, which was $0.915 \mathrm{~s}^{-1}$ and followed by carboxymethyl chitosan $\left(0.701 \mathrm{~s}^{-1}\right)$ and swollen chitin $\left(0.693 \mathrm{~s}^{-1}\right)$. The results support the $\mathrm{V}_{\max }$ value that indicated that CHI II had a lower turnover efficiency towards carboxymethyl chitosan and swollen chitin than towards colloidal chitin. However, the specificity constant $\mathrm{k}_{\mathrm{cat}} / \mathrm{K}_{\mathrm{m}}$ is generally a better indication of the catalytic efficiency than $\mathrm{k}_{\mathrm{cat}}$ alone [48]. Comparable with the $\mathrm{K}_{\mathrm{m}}$ value, the $\mathrm{k}_{\mathrm{cat}} / \mathrm{K}_{\mathrm{m}}$ values suggested that CHI II had a higher catalytic efficiency towards swollen chitin than colloidal chitin and carboxymethyl chitosan at low temperatures. A previous study found that a higher $\mathrm{K}_{\mathrm{m}}$ and $\mathrm{k}_{\text {cat }}$ are also characteristics of lactate dehydrogenase (LDH-A4) enzymes from a cold-water fish where a higher $K_{m}$ results in a decrease in $\Delta G_{E S}$, with a concomitant decrease in the energy of activation required to form the transition state, thereby increasing the $\mathrm{k}_{\mathrm{cat}}$ [49]. Therefore, the strategy used to maintain sustainable activity at a permanently low temperature is to enhance the $\mathrm{k}_{\text {cat }}$ and $\mathrm{k}_{\text {cat }} / \mathrm{K}_{\mathrm{m}}$ values instead of decreasing the $\mathrm{K}_{\mathrm{m}}$ [50].

\section{Conclusion}

In this study, a chitinase from G. antarctica PI12 was isolated, purified and characterised. The protein displays an optimum catalytic activity at an apparently low temperature and $\mathrm{pH}$. Due to its high versatility regarding its $\mathrm{pH}$ range, temperature range and substrate specificity towards chitin polymers, the G. antarctica PI12 family 18 chitinase seems to be a highly attractive enzyme for the production of chitooligosaccharides, and more generally for biotechnological applications such as for the biocontrol of microbial spoilage of refrigerated foods and use as a mycoparasite of phytopathogenic fungi in cold environments.

\section{Methods}

Microorganisms, plasmids, growth media, enzymes and reagents

The psychrophilic yeast, G. antarctica PI12 was obtained from School of Biosciences \& Biotechnology, Universiti Kebangsaan Malaysia, Malaysia. Escherichia coli JM109 (Promega) was used as cloning host. The pPICZ $\alpha$ A vector (Invitrogen), which can propagate in both bacterial and yeast systems, was used for initial cloning in bacteria and subsequent expression in yeast. P. pastoris GS115 (Invitrogen) was used for heterologous protein expression. G. antarctica PI12 was grown on Yeast extract Peptone Dextrose (YPD) and chitinase induction medium $(0.3 \%(\mathrm{w} / \mathrm{v})$ yeast extract, $0.5 \%(\mathrm{w} / \mathrm{v})$ peptone, $0.3 \%(\mathrm{w} / \mathrm{v}) \mathrm{NaCl}$ and $3 \%(\mathrm{w} / \mathrm{v})$ colloidal chitin), both containing $25 \mu \mathrm{g} / \mathrm{ml}$ ampicillin and $25 \mu \mathrm{g} / \mathrm{ml} \mathrm{kana-}$ mycin. The $G$. antarctica PI12 cells were incubated at $4^{\circ}$ C for 7 to 8 days. E. coli JM109 was grown in Luria Bertani (LB) medium with $100 \mu \mathrm{g} / \mathrm{ml}$ ampicillin as a selectable antibiotic. Media and protocols used for P. pastoris are described in the Pichia expression manual (Invitrogen). Restriction enzymes were obtained from Promega and New England Biolabs (NEB), while all other chemicals were of analytical grade and were obtained from Sigma, Amresco, Fluka or Merck.

\section{Total RNA isolation and CDNA synthesis of the full-length chitinase gene}

Total RNA was extracted from G. antarctica PI12 using a method as described by Sokolovsky et al. [51]. Briefly, G. antarctica PI12 was grown at $4^{\circ} \mathrm{C}$ for seven days in chitinase induction medium. RNA was purified and used immediately for cDNA synthesis or stored at $-80^{\circ} \mathrm{C}$. All primers used in PCR amplifications are listed in Table 2. The partial cDNA fragment of G. antarctica PI12 chitinase was amplified using primers LChi (F) and LChi (R) and an RT-PCR System (Promega), as recommended by the manufacturer. The primers were designed based on the Genome Sequencing Survey (GSS) Database of G. antarctica PI12 available at Malaysia Genome Institute (MGI). The resulting DNA fragment was used as a template for a subsequent RACE amplification to obtain the full-length $\mathrm{CHI}$ II sequence. 3' RACE was performed using primer 3-RC and a CapFishing ${ }^{\text {TM}}$ full-length cDNA Premix kit (Seegene) while 5' RACE was performed using primer 5-RC and a 
Table 2 PCR primers used in this study

\begin{tabular}{llll}
\hline Primer name & Sequence $\left(\mathbf{5}^{\prime}\right.$-' $\left.\mathbf{3}^{\prime}\right)$ & Orientation & Use \\
\hline LChi (F) & GAGAATCGCAACTGACTT & Forward & RT-PCR \\
LChi (R) & GCAGGTGATCAGACGG & Reverse & RT-PCR \\
3-RC & AGGAAACCAGATCGGGATGT ACTGGCC & Forward & RACE amplification \\
$5-$ RC & GTCGTCGCGCTCCAGGAGCCATAAAT & Reverse & RACE amplification \\
CHI-For & ATGAAGATCCCTCTCCTCTCCTCC & Forward & RT-PCR \\
CHI-Rev & CTACGCCTTGAACGTCCCCGCCAGT & Reverse & RT-PCR \\
CHI-Notl & TITGCGGCCGCTCACCCCTACCACTCCCTC & Forward & PCR \\
CHI-Xbal & TITCTAGAACGCCTTGACGTCC CCGCCAGT & Reverse & PCR \\
\hline
\end{tabular}

The location of Notl and Xbal are underlined

SMARTTM RACE cDNA Amplification kit (Clontech), as recommended by the manufacturers. Using the sequence information from the RACE result, the full-length gene of chitinase was amplified using primer CHI-Rev and CHI-For via RT-PCR. DNA sequences amplified by PCR were confirmed by nucleotide sequencing (First BASE Laboratories).

\section{Multiple sequence alignment and phylogenetic analysis} The phylogenetic relationship of CHI II was generated with 24 other deduced chitinases available from the NCBI databases as shows in Table 3. A phylogenetic tree was constructed by multiple sequence alignment using clustal X [52] and was generated using the NeighbourJoining method (NJ) and bootstrap analysis. The phylogenetic tree was visualised using Treeview software. Confidence values for individual branches were assessed from 1000 bootstrap replicates of the original sequence data.

\section{Construction of the chitinase expression plasmid and yeast transformants}

The mature CHI II sequence was PCR amplified using primers $\mathrm{CHI}-\mathrm{Not} \mathrm{I}$ and $\mathrm{CHI}-\mathrm{XbaI}$ and with the fulllength cDNA as a template. The resulting DNA fragment (1100 bp) was digested with NotI and XbaI before being ligated into the corresponding sites of the pPIC$\mathrm{Z} \alpha \mathrm{A}$ vector and termed plasmid CHI II-pPICZ $\alpha$ A. The recombinant enzyme was constructed such that the native signal peptide of the G. antarctica PI12 chitinase was replaced by the Saccharomyces cerevisiae $\alpha$-factor signal peptide and was cloned in frame with the C-terminal tag. The ligation product was transformed into $E$. coli JM109. The correct sequence of the expression plasmid was confirmed by DNA sequencing.

Transformation of recombinant $\mathrm{CHI}$ II into $P$. pastoris GS115 was performed as recommended by the manufacturer (Invitrogen). Briefly, CHI II-pPICZ $\alpha$ A was linearised using PmeI. The purified DNA product $(2-5 \mu \mathrm{g})$ was transformed into competent $P$. pastoris GS115 cells via electroporation. Transformants were selected by plating onto YPD agar plates containing $100 \mu \mathrm{g} / \mathrm{ml}$ zeocin. The methanol metabolisation phenotype $\left(\mathrm{Mut}^{+}\right)$ of $P$. pastoris recombinants was analysed by colony PCR using universal primers 5' AOX and 3' AOX. Colonies that produced a $1700 \mathrm{bp}$ (plus the size of the parent plasmid) PCR product were selected and kept for subsequent analysis.

\section{Expression of recombinant $\mathrm{CHI}$ II in P. pastoris GS115}

$P$. pastoris GS115 transformants were grown in $100 \mathrm{ml}$ of fresh Buffered Complex Medium containing Glycerol termed as BMGY medium (1\% (w/v) yeast extract, $2 \%$ $(\mathrm{w} / \mathrm{v})$ peptone, $100 \mathrm{mM}$ potassium phosphate $(\mathrm{pH} 6.0)$, $1.34 \% \mathrm{YNB}, 4 \times 10^{-5} \%$ biotin and $1 \%(\mathrm{v} / \mathrm{v})$ glycerol) in a $1000 \mathrm{ml}$ baffled flask at $29^{\circ} \mathrm{C}$ and $250 \mathrm{rpm}$ until the culture reached an $\mathrm{A}_{600}$ of 2-6 (approximately 18-20 hours). To induce CHI II production in P. pastoris, the cells were harvested and resuspended in Buffered Complex Medium containing Methanol or known as BMMY medium (1\% $(\mathrm{w} / \mathrm{v})$ yeast extract, $2 \%(\mathrm{w} / \mathrm{v})$ peptone, $100 \mathrm{mM}$ potassium phosphate $(\mathrm{pH} 6.0), 1.34 \% \mathrm{YNB}, 4 \times 10^{-5} \%$ biotin and $0.5 \%(\mathrm{v} / \mathrm{v})$ methanol) using $1 / 5$ of the original culture volume $(20 \mathrm{ml})$. Absolute methanol was added every 24 hours to a final concentration of $1 \%(\mathrm{v} / \mathrm{v})$ to maintain induction. To analyse expression levels and the optimal time post-induction for harvest, the culture supernatant was collected at 1, 2, 3, 4 and 5 days. Expression of secreted proteins was analysed by SDS-PAGE.

\section{Purification of recombinant chitinase}

All purification steps were performed at $4^{\circ} \mathrm{C}$. The crude enzyme was concentrated by an Amicon concentrator 10,000 MWCO (MILIPORE) followed by purification using HisTrap ${ }^{\mathrm{TM}}$ HP Columns (GE Healthcare). The purified protein was collected and characterised further. The purified proteins were analysed by SDS-PAGE on a $10 \%$ gradient gel.

\section{Measurement of enzyme activity and protein determination}

Chitinase activity was measured using 3, 5-dinitrosalicylic acid (DNS) as described by Miller et al. [53] but 
Table 3 Chitinases from different organisms used in the phylogenetic analysis

\begin{tabular}{|c|c|c|c|}
\hline Taxanomy & Name/source & Abbreviation & Accession No \\
\hline \multicolumn{4}{|l|}{ Bacteria; } \\
\hline Proteobacteria & Collimonas fungivorans & C.fungivorans & ACF93784 \\
\hline \multirow[t]{9}{*}{ Firmicutes } & Brevibacillus brevis & B.brevis & YP_002771189 \\
\hline & Paenibacillus sp. & Paenibacil & ZP_04850994 \\
\hline & Bacillus circulans & B.circulans & AAF74782 \\
\hline & Bacillus halodurans & B.halodura & NP_241782 \\
\hline & Kurthia zopfii & K.zopfii & BAA09831 \\
\hline & Clostridium papyrosolvens & C.papyroso & ZP_03226994 \\
\hline & Bacillus coahuilensis & B. coahuile & ZP_03226994 \\
\hline & Bacillus thuringiensis & B. thuringi & ABQ65137 \\
\hline & Bacillus mycoides & B.mycoides & ZP_04167090 \\
\hline \multirow[t]{2}{*}{ Bacteroidetes } & Rhodothermus marinus & R.marinus & ZP_04424886 \\
\hline & Spirosoma linguale & S.linguale & ZP_04488661 \\
\hline \multicolumn{4}{|l|}{ Archaea; } \\
\hline \multirow[t]{2}{*}{ Euryarchaeota } & Thermococcus kodakarensis & T.kodakare & YP_184178 \\
\hline & Halogeometricum borinquense & H.borinquense & ZP_04000472 \\
\hline \multicolumn{4}{|l|}{ Eukaryota; } \\
\hline \multicolumn{4}{|l|}{ Metazoa; } \\
\hline \multicolumn{4}{|l|}{ Arthropoda; } \\
\hline \multicolumn{4}{|l|}{ Hexapoda; } \\
\hline \multirow[t]{3}{*}{ Insecta } & Aedes aegypti & A.aegypti & XP_001656054 \\
\hline & Tribolium castaneum & T. castaneu & NP_001038094 \\
\hline & Culex quinquefasciatus & C. quinquefasciatus & XP_001867701 \\
\hline \multicolumn{4}{|l|}{ Chordata; } \\
\hline \multicolumn{4}{|l|}{ Craniata; } \\
\hline Vertebrata & Mus musculus & M.musculus & ABK78778 \\
\hline \multicolumn{4}{|l|}{ Fungi; } \\
\hline \multicolumn{4}{|l|}{ Dikarya; } \\
\hline \multirow[t]{6}{*}{ Basidiomycota } & Amanita muscaria & A.muscaria & CAC35202.1 \\
\hline & Puccinia triticina & P.triticin & AAP42832.1 \\
\hline & Laccaria bicolor & L.bicolor & XP_001886180 \\
\hline & Coprinellus congregatus & C.congregatus & CAQ51152 \\
\hline & Cryptococcus neoformans & C.neoforma & XP_572898 \\
\hline & Taiwanofungus camphoratus & T.camphora & ABB90389 \\
\hline
\end{tabular}

with some modifications. The reaction mixture contained $0.25 \mathrm{ml}$ of $10 \%$ colloidal chitin in $0.2 \mathrm{M}$ sodium acetate buffer ( $\mathrm{pH} 4.0$ ) and $0.25 \mathrm{ml}$ enzyme solution. After an incubation at $15^{\circ} \mathrm{C}$ for $1 \mathrm{~h}$, the reaction was terminated by boiling at $100^{\circ} \mathrm{C}$ for $5 \mathrm{~min}$. The reaction mixture was centrifuged at $8,000 \times \mathrm{g}$ for $1 \mathrm{~min}$. Next, $0.75 \mathrm{ml}$ of DNS reagent was added to the aliquots of $0.25 \mathrm{ml}$ reaction mixture that was then boiled at $100^{\circ} \mathrm{C}$ for $10 \mathrm{~min}$. After cooling, the reducing sugars that were released as a result of the chitinase activity were measured at $540 \mathrm{~nm}$ using a UV spectrophotometer. One unit (U) of the chitinase activity is defined as the amount of enzyme that is required to release $1 \mu \mathrm{mol}$ of $\mathrm{N}$-acetyl- $\beta$-D-glucosamine per hour under the assay conditions. Protein content was measured according to the method of Bradford [54] using bovine serum albumin (BSA) as a protein standard. The reaction was measured at a wavelength of $595 \mathrm{~nm}$.

\section{SDS-PAGE, western blot and glycosylation analysis of chitinase}

Sodium dodecyl sulphate-polyacrylamide gel electrophoresis (SDS-PAGE) was conducted to analyse the recombinant protein expression by the method of Laemmli [55] and the gel was then stained with $1 \%$ Coomassie Brilliant Blue R250 . Western blotting was performed by colorimetric detection using a His-Tag monoclonal antibody, as recommended by the manufacturer (Novagen). Glycoprotein sugar moieties in the polyacrylamide gel were detected using a GelCode glycoprotein staining kit (Pierce Biotechnology) according to the instructions provided by the manufacturer. 


\section{Characterisation of purified $\mathrm{CHI}$ II}

The optimum $\mathrm{pH}$ for the purified CHI II was evaluated at $15^{\circ} \mathrm{C}$ over a $\mathrm{pH}$ range of 2.5 to 8.0 , using appropriate buffers $(100 \mathrm{mM})$, citrate-phosphate buffer (pH 2.5 to 6.5) and potassium phosphate buffer ( $\mathrm{pH} 6.0$ to 8.0), under $\mathrm{CHI}$ II chitinase assay procedures. The $\mathrm{pH}$ stability of the enzyme was investigated further at $15^{\circ} \mathrm{C}$ by pre-incubation of the enzyme solutions in the described buffer systems in the absence of substrate for $30 \mathrm{~min}$. The reaction mixture was then subjected to the CHI II chitinase assay and a $\mathrm{pH}$ profile was produced with the enzyme activity at the optimum $\mathrm{pH}$ set to $100 \%$.

The optimum temperature for purified CHI II activity was measured by incubating the purified enzyme for $30 \mathrm{~min}$ at temperatures ranging from $5^{\circ} \mathrm{C}$ to $30^{\circ} \mathrm{C}$. The thermostability of $\mathrm{CHI}$ II was also investigated at temperatures of $5^{\circ} \mathrm{C}$ to $30^{\circ} \mathrm{C}$ after incubation of the enzyme solutions in the absence of substrate for 30 min. A temperature profile was produced with the enzyme activity at the optimum temperature set to $100 \%$.

Metal ions are generally considered to be important factors affecting microbial enzyme activity. The reaction mixture consisted of purified enzyme in $100 \mathrm{mM}$ citrate buffer ( $\mathrm{pH} 4.0$ ) containing $1 \mathrm{mM}$ metal ions $\left(\mathrm{K}^{+}, \mathrm{Cu}^{2+}\right.$, $\mathrm{Mn}^{2+}, \mathrm{Fe}^{2+}, \mathrm{Co}^{2+}, \mathrm{Ca}^{2+}, \mathrm{Na}^{+}$and $\mathrm{Zn}^{2+}$ ) and different reagents (such as $1 \mathrm{mM}$ EDTA and 1\% SDS). The effect of these metal ions was investigated using the CHI II chitinase assay system. The system without any additives was used as a control.

\section{Substrate specificity and kinetic parameters}

The substrate specificity of CHI II was determined by measuring the enzyme activity after incubation in 100 $\mathrm{mM}$ citrate buffer containing $1 \%$ of each substrate (colloidal chitin, swollen chitin, glycol chitosan and carboxymethyl chitosan) at $\mathrm{pH} 4.0$ and $15^{\circ} \mathrm{C}$ for $1 \mathrm{~h}$. The amount of reducing sugars produced was estimated by using the DNS method as described above. The kinetic parameters $\left(\mathrm{K}_{\mathrm{m}}, \mathrm{V}_{\max }, \mathrm{k}_{\mathrm{cat}}\right.$, and $\left.\mathrm{k}_{\mathrm{cat}} / \mathrm{K}_{\mathrm{m}}\right)$ of the purified enzyme were studied. Different substrate (colloidal chitin, swollen chitin and carboxymethyl chitosan) concentrations were used, ranging from 2.0 to $10.0 \mathrm{mg} \mathrm{ml}^{-1}$. The reaction rate versus substrate concentration was plotted to determine whether the enzyme obeys Michaelis-Menten kinetics. The Michaelis-Menten constant $\left(\mathrm{K}_{\mathrm{m}}\right)$ and maximum velocity of substrate hydrolysis $\left(\mathrm{V}_{\max }\right)$ were determined from the Lineweaver-Burk plots.

\section{Acknowledgements}

This work was supported by a research grant from the Molecular Biology \& Genomic Initiative Program, Malaysia Genome Institute (Project No. 07-05-16MGI-GMB02).

\section{Author details}

${ }^{1}$ Department of Bioprocess Engineering, Faculty of Chemical Engineering, Universiti Teknologi Malaysia, 81310 Skudai, Johor, Malaysia. ${ }^{2}$ Malaysia Genome Institute (MGI), Jalan Bangi Lama, 43000 Kajang, Selangor, Malaysia. ${ }^{3}$ School of Biosciences and Biotechnology, Faculty of Science and Technology, Universiti Kebangsaan Malaysia, 43600 Bangi, Selangor, Malaysia.

\section{Authors' contributions}

NMM, RMI developed the concept and design the study. ANMR performed experiments and wrote the manuscript. AR, AMAM, FDAB, RMI edited the manuscript. RMI gave technical support and conceptual advice. All authors have approved the final article to be submitted as manuscript.

\section{Competing interests}

The authors declare that they have no competing interests.

Received: 19 July 2011 Accepted: 4 November 2011

Published: 4 November 2011

\section{References}

1. Bae E, Phillips GN: Structures and Analysis of Highly Homologous Psychrophilic, Mesophilic, and Thermophilic Adenylate Kinases. Journal of Biological Chemistry 2004, 279:28202-28208.

2. Cavicchioli R, Siddiqui KS, Andrews D, Sowers KR: Low-temperature extremophiles and their applications. Current Opinion in Biotechnology 2002, 13:253-261.

3. Collins T, Meuwis M-A, Gerday C, Feller G: Activity, Stability and Flexibility in Glycosidases Adapted to Extreme Thermal Environments. Journal of Molecular Biology 2003, 328:419-428.

4. Joseph B, Ramteke PW, Thomas G: Cold active microbial lipases: Some hot issues and recent developments. Biotechnology Advances 2008, 26:457-470.

5. Feller G, Lonhienne T, Deroanne C, Libioulle C, Van Beeumen J, Gerday C: Purification, characterization, and nucleotide sequence of the thermolabile alpha-amylase from the antarctic psychrotroph Alteromonas haloplanctis A23. Journal of Biological Chemistry 1992, 267:5217-5221.

6. Lonhienne T, Mavromatis K, Vorgias CE, Buchon L, Gerday C, Bouriotis V: Cloning, Sequences, and Characterization of Two Chitinase Genes from the Antarctic Arthrobacter sp. Strain TAD20: Isolation and Partial Characterization of the Enzymes. The Journal of Bacteriology 2001, 183:1773-1779.

7. Stefanidi E, Vorgias C: Molecular analysis of the gene encoding a new chitinase from the marine psychrophilic bacterium Moritella marina and biochemical characterization of the recombinant enzyme. Extremophiles 2008, 12:541-552.

8. Kubicek CP, Mach RL, Peterbauer CK, Lorito M: Trichoderma: From genes to biocontrol. Journal of Plant Pathology 2001, 83:11-23.

9. Dahiya N, Tewari R, Tiwari RP, Hoondal GS: Chitinase from Enterobacter sp. NRG4: Its purification, characterization and reaction pattern. Electronic Journal of Biotechnology 2005, 8:134-145.

10. Gooday GW: Physiology of microbial degradation of chitin and chitosan. Biodegradation 1990, 1:177-190.

11. Patil RS, Ghormade V, Deshpande MV: Chitinolytic enzymes: an exploration. Enzyme and Microbial Technology 2000, 26:473-483.

12. Dahiya N, Tewari R, Hoondal G: Biotechnological aspects of chitinolytic enzymes: a review. Applied Microbiology and Biotechnology 2006, 71:773-782.

13. Xiao X, Yin X, Lin J, Sun L, You Z, Wang P, Wang F: Chitinase genes in lake sediments of Ardley Island, Antarctica. Applied and Environmental Microbiology 2005, 71:7904-7909.

14. McCreath KJ, Specht CA, Robbins PW: Molecular cloning and characterization of chitinase genes from Candida albicans. Proceedings of the National Academy of Sciences of the United States of America 1995, 92:2544-2548.

15. Henrissat B, Bairoch A: New families in the classification of glycosyl hydrolases based on amino acid sequence similarities. Biochemical Journal 1993, 293:781-788.

16. Tronelli D, Maugini E, Bossa F, Pascarella S: Structural adaptation to low temperatures - analysis of the subunit interface of oligomeric psychrophilic enzymes. FEBS Journal 2007, 274:4595-4608. 
17. Orikoshi H, Baba N, Nakayama S, Kashu H, Miyamoto K, Yasuda M, Inamori $\mathrm{Y}$, Tsujibo $\mathrm{H}$ : Molecular analysis of the gene encoding a novel cold-adapted chitinase (ChiB) from a marine bacterium, Alteromonas sp. Strain 0-7. The Journal of Bacteriology 2003, 185:1153-1160.

18. Nakamura T, Ishikawa M, Nakatani H, Oda A: Characterization of coldresponsive extracellular chitinase in bromegrass cell cultures and its relationship to antifreeze activity. Plant Physiology 2008, 147:391-401.

19. Fenice M, Selbmann L, Di Giambattista R, Federici F: Chitinolytic activity at low temperature of an Antarctic strain (A3) of Verticillium lecanii. Research in Microbiology 1998, 149:289-300.

20. Papa R, Rippa V, Sannia G, Marino G, Duilio A: Recombinant protein expression system in cold loving microorganisms. Microbial Cell Factories 2006, 5:1-2.

21. Feller $G$, Thiry M, Arpigny $\lrcorner$, Gerday C: Cloning and expression in Escherichia coli of three lipase-encoding genes from the psychrotrophic antarctic strain Moraxella TA144. Gene 1991, 102:111-115.

22. Jahic M, Wallberg F, Bollok M, Garcia P, Enfors S-O: Temperature limited fed-batch technique for control of proteolysis in Pichia pastoris bioreactor cultures. Microbial Cell Factories 2003, 2:6.

23. Gan Z, Yang J, Tao N, yu Z, Zhang K-Q: Cloning and expression analysis of a chitinase gene Crchi1 from the mycoparasite fungus Clonostachys rosea (syn. Gliocladium roseum). The Journal of Mirobiology 2007, 45:422-430.

24. Wang Y-J, Yang Q: Cloning and Expression of a Novel Chitinase chi58 from Chaetomium cupreum in Pichia pastoris. Biochemical Genetics 2009. 47:547-558.

25. Bendt A, Hüller H, Kammel U, Helmke E, Schweder T: Cloning, expression, and characterization of a chitinase gene from the Antarctic psychrotolerant bacterium Vibrio sp. strain Fi:7. Extremophiles 2001, 5:119-126.

26. Dyrløv Bendtsen J, Nielsen $H$, von Heijne G, Brunak S: Improved Prediction of Signal Peptides: SignalP 3.0. Journal of Molecular Biology 2004, 340:783-795

27. Gupta R, Brunak S: Prediction of glycosylation across the human proteome and the correlation to protein function. Pacific Symposium on Biocomputing 2002, 310-322.

28. Hunter S, Apweiler R, Attwood TK, Bairoch A, Bateman A, Binns D, Bork P, Das U, Daugherty L, Duquenne L, et al: InterPro: the integrative protein signature database. Nucleic Acids Research 2009, 37:D211-D215.

29. Wang S-Y, Wu S-J, Thottappilly G, Locy RD, Singh NK: Molecular cloning and structural analysis of the gene encoding Bacillus cereus exochitinase Chi36. Journal of Bioscience and Bioengineering 2001, 92:59-66.

30. Limón MC, Chacón MR, Mejías R, Delgado-Jarana J, Rincón AM, Codón AC, Benítez T: Increased antifungal and chitinase specific activities of Trichoderma harzianum CECT 2413 by addition of a cellulose binding domain. Applied Microbiology and Biotechnology 2004, 64:675-685.

31. Liu ZH, Yang Q, Hu S, Zhang JD, Ma J: Cloning and characterization of a novel chitinase gene (chi46) from Chaetomium globosum and identification of its biological activity. Applied Microbiology and Biotechnology 2008, 80:241-252.

32. Gan Z, Yang J, Tao N, Liang L, Mi Q, Li J, Zhang K-Q: Cloning of the gene Lecanicillium psalliotae chitinase Lpchi1 and identification of its potential role in the biocontrol of root-knot nematode Meloidogyne incognita. Applied Microbiology and Biotechnology 2007, 76:1309-1317.

33. Kawase T, Saito A, Sato T, Kanai R, Fujii T, Nikaidou N, Miyashita K, Watanabe T: Distribution and phylogenetic analysis of family 19 chitinases in Actinobacteria. Appl Environ Microbiol 2004, 70:1135-1144.

34. Mattanovich D, Gasser B, Hohenblum H, Sauer M: Stress in recombinant protein producing yeasts. Journal of Biotechnology 2004, 113:121-135.

35. Hong F, Meinander NQ, Jönsson LJ: Fermentation strategies for improved heterologous expression of laccase in Pichia pastoris. Biotechnology and Bioengineering 2002, 79:438-449.

36. Lee SG, Koh HY, Han SJ, Park H, Na DC, Kim I-C, Lee HK, Yim JH: Expression of recombinant endochitinase from the Antarctic bacterium, Sanguibacter antarcticus KOPRI 21702 in Pichia pastoris by codon optimization. Protein Expression and Purification 2010, 71:108-114.

37. Julenius K, MÃ, lgaard A, Gupta R, Brunak S: Prediction, conservation analysis, and structural characterization of mammalian mucin-type O-glycosylation sites. Glycobiology 2005, 15:153-164.

38. You M, Xuan X, Tsuji N, Kamio T, Taylor D, Suzuki N, Fujisaki K: Identification and molecular characterization of a chitinase from the hard tick Haemaphysalis longicornis. Journal of Biological Chemistry 2003, 278:8556-8563.
39. Park S-M, Kim D-H, Truong NH, Itoh Y: Heterologous expression and characterization of class III chitinases from rice (Oryza sativa L.). Enzyme and Microbial Technology 2002, 30:697-702

40. El-Katatny MH, Gudelj M, Robra KH, Elnaghy MA, Gubitz GM: Characterization of a chitinase and an endo-beta-1,3-glucanase from Trichoderma harzianum Rifai T24 involved in control of the phytopathogen Sclerotium rolfsii. Applied Microbiology and Biotechnology 2001, 56:137-143

41. Chen WM, Chen GH, Chen CS, Jiang ST: Cloning, expression and purification of Bacillus cereus endochitinase in the Escherichia coli AD494 (DE3)pLysS Expression System. Bioscience, Biotechnology and Biochemistry 2009, 73:1172-1174.

42. Alias N, Mahadi N, Murad A, Bakar F, Mahmood N, Illias R: Expression and characterization of Trichoderma virens UKM-1 endochitinase in Escherichia coli. World Journal of Microbiology and Biotechnology 2009 25:561-572.

43. Sandhya C, Adapa LK, Nampoothiri KM, Binod P, Szakacs G, Pandey A: Extracellular chitinase production by Trichoderma harzianum in submerged fermentation. Journal of Basic Microbiology 2004, 44:49-58.

44. Yano S, Rattanakit N, Wakayama M, Tachiki T: A chitinase indispensable for formation of protoplast of Schizophyllum commune in basidiomycetelytic enzyme preparation produced by Bacillus circulans KA-304. Bioscience, Biotechnology and Biochemistry 2004, 68:1299-1305.

45. Bhushan B, Hoondal GS: Isolation, purification and properties of a thermostable chitinase from an alkalophilic Bacillus sp. BG-11. Biotechnology Letters 1998, 20:157-159.

46. Woo C-J, Park H-D: An extracellular Bacillus sp. chitinase for the production of chitotriose as a major chitinolytic product. Biotechnology Letters 2003, 25:409-412.

47. Siddiqui KS, Cavicchioli R: Cold-adapted enzymes. Annual Review of Biochemistry 2006, 75:403-433.

48. Feller G: Molecular adaptations to cold in psychrophilic enzymes. Cellular and Molecular Life Sciences 2003, 60:648-662.

49. Fields PA, Somero GN: Hot spots in cold adaptation: Localized increases in conformational flexibility in lactate dehydrogenase A4 orthologs of Antarctic notothenioid fishes. Proceedings of the National Academy of Sciences 1998, 95:11476-11481.

50. D'Amico S, Gerday C, Feller G: Structural determinants of cold adaptation and stability in a psychrophilic a-amylase. Biologia (Bratislava) 2002, 57:213-219.

51. Sokolovsky VY, Kaldenhoff R, Ricci M, Russo VEA: Fast and reliable miniprep RNA extraction from Neurospora crassa. Fungal Genetics Newsletters 1990, 37:39-40.

52. Thompson JD, Gibson TJ, Higgins DG: Multiple Sequence Alignment Using ClustalW and ClustalX. Current Protocols in Bioinformatics John Wiley \& Sons, Inc; 2002.

53. Miller GL: Use of dinitrosalicylic acid reagent for determination of reducing sugar. Analytical Chemistry 1959, 31:426-428.

54. Bradford MM: A rapid and sensitive method for the quantitation of microgram quantities of protein utilizing the principle of protein-dye binding. Analytical Biochemistry 1976, 72:248-254

55. Laemmli UK: Cleavage of structural proteins during the assembly of the head of bacteriophage T4. Nature 1970, 227:680-685.

56. Kuranda MJ, Robbins PW: Chitinase is required for cell separation during growth of Saccharomyces cerevisiae. Journal of Biological Chemistry 1991, 266:19758-19767.

57. Fitches E, Wilkinson H, Bell H, Bown DP, Gatehouse JA, Edwards JP: Cloning, expression and functional characterisation of chitinase from larvae of tomato moth (Lacanobia oleracea): a demonstration of the insecticidal activity of insect chitinase. Insect Biochemistry and Molecular Biology 2004 34:1037-1050.

58. Watanabe T, Oyanagi W, Suzuki K, Ohnishi K, Tanaka H: Structure of the gene encoding chitinase D of Bacillus circulans WL-12 and possible homology of the enzyme to other prokaryotic chitinases and class III plant chitinases. J Bacteriol 1992, 174:408-414.

doi:10.1186/1475-2859-10-94

Cite this article as: Ramli et al: Molecular cloning, expression and biochemical characterisation of a cold-adapted novel recombinant chitinase from Glaciozyma antarctica PI12. Microbial Cell Factories 2011 10:94. 